\title{
KAJIAN VARIASI KONSENTRASI SUKROSA TERHADAP KARAKTERISTIK NATA TIMUN SURI (Cucumis sativus L.)
}

\section{STUDY OF SUCROSE CONCENTRATION VARIATION TO NATA DE CUCUMBER CHARACTERISTICS (Cucumis sativus L.)}

\author{
Netty Herawaty ${ }^{1)}$, Methatias Ayu Moulina ${ }^{2)}$ \\ 1) Program Studi Teknologi Pertanian, Fakultas Pertanian, UNIVED \\ 2) Program Studi Teknologi Pangan, Fakultas Pertanian, UNIVED
}

\begin{abstract}
ABSTRAK
Nata adalah suatu zat yang menyerupai gel, tidak larut dalam air dan terbentuk pada permukaan media fermentasi air kelapa atau beberapa sari buah masam. Pembuatan nata melibatkan jasad renik (mikroba) yang dikenal dengan nama Acetobacter xylinum. Nata merupakan salah satu jenis makanan berbentuk gel (agar-agar) dengan tekstur agak kenyal, padat, putih dan sedikit transparan. Tujuan dari penelitian ini adalah untuk mengetahui pengaruh penambahan sukrosa terhadap karakteristik mutu fisik, kimia, dan organoleptik nata timun suri serta penentuan konsentrasi sukrosa yang paling tepat dalam pengolahan nata timun suri. Rancangan percobaan yang digunakan dalam penelitian ini adalah Rancangan Acak Lengkap (RAL) dengan faktor tunggal. Faktor yang digunakan sebagai perlakuan adalah penambahan konsentrasi sukrosa yaitu : konsentrasi sukrosa $4 \%=40 \mathrm{gr}$, konsentrasi sukrosa $6 \%=60$ gr, konsentrasi sukrosa $8 \%=80$ gr, konsentrasi sukrosa $10 \%$ $=100$ gr, dan konsentrasi sukrosa $12 \%=120$ gr. Penelitian yang dilakukan meliputi : analisis pengukuran ketebalan, tekstur, kadar serat, dan uji organoleptik nata timun suri. Hasil terbaik diperoleh pada penambahan sukrosa $10 \%$ dengan ketebalan $1,1 \mathrm{~cm}$, tekstur $2,57 \mathrm{kgf} / \mathrm{cm}^{2}$, dan kadar serat $1,11 \%$. Hasil uji organoleptik dari tingkat penerimaan panelis terhadap parameter warna panelis lebih menyukai penambahan sukrosa $12 \%$ dengan nilai 3,85, sedangkan parameter rasa dan tekstur panelis lebih menyukai penambahan sukrosa $10 \%$ dengan nilai 4,1 dan 3,95 . Konsentrasi sukrosa yang terbaik dalam pengolahan nata timun suri adalah $10 \%$.
\end{abstract}

Kata Kunci : Nata de Timun Suri, Timun Suri, Sukrosa.

\section{ABSTRACT}

Nata is a gel-like substances, insoluble in water and is formed on the surface of the fermentation medium coconut water or some sour juice. Making nata involving microorganisms (microbes) are known as Acetobacter xylinum. Nata is one type of food gel (agar-agar) with slightly chewy texture, dense, white and slightly transparent. The purpose of this study was to determine the effect of sucrose on the quality characteristics of the physical, chemical, and organoleptic nata cucumber and determining the most appropriate sucrose concentrations in processing cucumber nata. The experimental design used in this study is completely randomized design (CRD) with a single factor. Factors used as treatment is the addition of sucrose concentration are : 4\% sucrose concentration $=40 \mathrm{~g}, 6 \%$ sucrose concentration $=60 \mathrm{~g}, 8 \%$ sucrose concentration $=80 \mathrm{~g}, 10 \%$ sucrose concentration $=100 \mathrm{~g}$, and $12 \%$ sucrose concentration $=120 \mathrm{~g}$. The research covers : analysis of thickness measurement, texture, fiber content, and organoleptic tests nata 
cucumber. The best results were obtained in 10\% sucrose with a thickness of $1,1 \mathrm{~cm}, 2,57$ $\mathrm{kgf} / \mathrm{cm}^{2}$ texture and fiber content $1,11 \%$. The results of organoleptic acceptance rate panelist to panelist color parameters like sucrose over $12 \%$ with a value of 3,85 , while the parameters of taste and texture panelists preferred the addition of $10 \%$ sucrose with a value of 4,1 and 3,95. The best sucrose concentration in the processing of nata cucumber is $10 \%$.

Keywords : Nata de Cucumber Suri, Suri Cucumber, Sucrose.

\section{PENDAHULUAN}

Era globalisasi yang ditandai dengan kemajuan ilmu pengetahuan dan teknologi (IPTEK) diikuti dengan kemajuan dalam pengolahan makanan yang semakin berkembang. Dengan kemajuan teknologi makanan ternyata diikuti oleh perubahan pola makan masyarakat yang biasanya dari pola makan yang mengandung karbohidrat, lemak, dan protein tetapi tidak mengandung banyak serat. Seiring berkembangnya ilmu pengetahuan terutama pada makanan masyarakat telah mengenal bahwa pentingnya serat bagi kesehatan untuk membantu dalam proses pencernaan sehingga timbul permintaan produk pangan yang kaya serat.

Makanan yang kaya akan serat salah satunya adalah nata. Nata merupakan makanan pencuci mulut (desert), yang mengandung serat selulosa kadar tinggi yang bermanfaat bagi kesehatan dalam membantu pencernaan. Nata adalah suatu bahan makanan hasil fermentasi oleh bakteri (Acetobacter xylinum) yang kaya akan selulosa bersifat kenyal, transparan dan rasanya menyerupai kolang-kaling.

Nata merupakan selulosa yang dibentuk oleh bakteri Acetobacter xylinum. Pengembangan produk nata diperkirakan mempunyai prospek yang cerah di masa mendatang. Hal ini didasarkan pada kenyataan bahwa semakin banyaknya industri nata yang berdiri dan semakin banyak pula nata beredar di pasaran. Selama ini bahan baku pembuatan nata yang sering digunakan adalah air kelapa (nata de coco), nanas (nata de pina), tomat (nata de tomato), dan buah-buahan lain yang cukup banyak mengandung karbohidrat (gula).

Produk makanan nata bukan merupakan sesuatu yang asing lagi di kalangan masyarakat, bentuknya yang seperti agaragar tetapi kenyal merupakan ciri khas tersendiri dari nata. Makanan ini bermanfaat untuk memperlancar penyerapan makanan dalam tubuh dan membantu penderita diabetes yang diet gula. Oleh karena itu produk ini dipakai sebagai sumber makanan berkalori rendah untuk keperluan diet. 
Di Indonesia banyak sekali berbagai macam jenis buah-buahan yang mengandung sumber vitamin dan mineral.

Salah satunya yaitu buah timun suri (Cucumis sativus L.) merupakan sumber serat yang sangat berguna bagi pencernaan makanan dalam tubuh manusia. Buah timun suri merupakan buah yang cepat mengalami kebusukan karena faktor lingkungan tak terkendali, maka untuk mencegah kebusukan buah timun suri dapat diolah sebagai alternatif pada pembuatan berbagai produk olahan timun suri, misalnya nata timun suri. Dalam hal ini penulis tertarik untuk melakukan penelitian membuat nata dari timun suri dengan variasi konsentrasi sukrosa terhadap karakteristik nata timun suri (Cucumis sativus L.)

\section{METODE PENELITIAN}

\section{Bahan dan Alat}

Bahan-bahan yang digunakan dalam penelitian ini adalah buah timun suri yang diambil dari kebun di daerah Pulau Baai Kota Bengkulu. Acetobacter xylinum, asam asetat dan ZA dibeli di Laboratorium Ilmu Hama dan Penyakit Tanaman (IHPT) UNIB, dan sukrosa (gula pasir) dibeli di pasar serta bahan kimia lainnya.

Alat-alat yang digunakan pada penelitian ini antara lain : panci, nampan plastik ukuran $35 \times 25 \times 4 \mathrm{~cm}$, gelas ukur, alat ukur $\mathrm{pH}$, timbangan, blender, saringan, kertas koran, pengikat/karet gelang, sendok/pengaduk, pisau, kompor dan alat analisis lainnya.

\section{Metode}

Penelitian ini dilakukan dengan cara pembuatan nata menurut Warisno (2004) yang dimodifikasi. Adapun tahapan pembuatan nata timun suri adalah sebagai berikut :

1. Alat-alat yang akan digunakan seperti nampan, saringan, gelas ukur dan sendok dicuci bersih kemudian dijemur sampai kering, dan kertas koran yang digunakan juga harus bersih dan dijemur agar steril.

2. Timun suri yang masak sebanyak 300 gr dikupas dan dibuang bijinya kemudian dicuci bersih.

3. Timun suri dipotong-potong dan dicampur dengan 1 liter air lalu diblender hingga halus.

4. Larutan disaring dengan menggunakan kain saring dan diambil ekstraknya sebanyak 1 liter untuk dijadikan sebagai bahan baku pengolahan nata.

5. Kemudian 1 liter ekstrak direbus bersama sukrosa dengan perlakuan (4\%, 6\%, 8\%, 10\%, dan 12\%), 5 gr ZA dan $20 \mathrm{ml}$ asam asetat, diaduk-aduk 
dan direbus hingga mendidih selama 15 menit.

6. Selagi panas dituang ke dalam nampan plastik lalu ditutup dengan kertas koran dan diikat dengan karet gelang.

7. Setelah itu didinginkan selama $3-4$ jam pada suhu ruang.

8. Setelah dingin ditambahkan starter sebanyak $100 \mathrm{ml}$ dan tutup kembali, kemudian difermentasi selama 7 hari sampai terbentuk lembaran nata.

9. Setelah 7 hari nata siap dipanen, pada waktu pemanenan dibuang lapisan tipis yang terdapat di atas permukaan lembaran nata lalu dicuci hingga bersih. Nata dilakukan analisa ketebalan, tekstur dan kadar serat.

10. Lembaran nata yang sudah bersih kemudian dipotong-potong segi empat seperti kubus, lalu direndam dalam air bersih selama 2 hari untuk menghilangkan asam, selama perendaman air rendaman harus diganti setiap hari.

11. Setelah direndam potongan nata direbus dengan air sampai mendidih selama 10 menit lalu ditiriskan, kemudian dibuat minuman nata dengan direbus kembali dan ditambahkan gula. Minuman nata dilakukan uji organoleptik berdasarkan parameter warna, rasa dan tekstur.

12. Nata yang direbus tanpa penambahan gula (nata murni) dilakukan uji organoleptik berdasarkan parameter warna, sedangkan nata yang direbus dengan penambahan gula (minuman nata) dilakukan uji berdasarkan parameter rasa dan tekstur.

Produk nata timun suri dalam penelitian ini, dilakukan analisis fisik, kimia dan organoleptik yang meliputi : Analisis mutu fisik yaitu analisis ketebalan (Yusmarini, dkk, 2004) dan analisis tekstur (Agus Purwanto, 2012) analisis mutu kimia yaitu analisis kadar serat (Apriyantono, 1992), analisis mutu organoleptik (Winarno, 2004).

\section{HASIL DAN PEMBAHASAN}

\section{Ketebalan Nata Timun Suri}

Berdasarkan hasil rerata analisa pengukuran ketebalan nata timun suri dengan perlakuan variasi konsentrasi sukrosa dapat dilihat pada tabel 1 dan gambar 1.

Tabel 1. Hasil Analisa Ketebalan (cm) Nata Timun Suri

\begin{tabular}{|l|l|}
\hline Konsentrasi Sukrosa (\%) & Ketebalan $(\mathrm{cm})$ \\
\hline
\end{tabular}




\begin{tabular}{|c|c|}
\hline 4 & $0.8^{\mathrm{b}}$ \\
\hline 6 & $0.9^{\mathrm{b}}$ \\
\hline 8 & $0.9^{\mathrm{b}}$ \\
\hline 10 & $1.1^{\mathrm{a}}$ \\
\hline 12 & $0.7^{\mathrm{c}}$ \\
\hline
\end{tabular}

Keterangan : Angka yang diikuti oleh kode huruf yang berbeda menunjukkan adanya perbedaan yang nyata pada taraf signifikansi $5 \%$.

Tabel 1 menjelaskan bahwa masingmasing perlakuan terdapat perbedaan yang nyata terhadap ketebalan nata. Ketebalan nata timun suri dengan perlakuan konsentrasi sukrosa $(4 \%, 6 \%$, 8\%) tidak berbeda nyata, sedangkan penambahan konsentrasi sukrosa $10 \%$ dan $12 \%$ terdapat beda nyata. Ketebalan nata tertinggi terjadi pada perlakuan penambahan sukrosa $10 \%$, yaitu $1,1 \mathrm{~cm}$, sedangkan ketebalan nata terendah terjadi pada perlakuan penambahan sukrosa $12 \%$, yaitu $0,7 \mathrm{~cm}$.

Ketebalan nata yang tinggi disebabkan karena penambahan sukrosa yang cukup, ini artinya sumber karbon dalam media fermentasi tercukupi sehingga selulosa yang disintesa bakteri Acetobacter xylinum banyak dan pelikel yang muncul juga tebal. Pada perlakuan penambahan sukrosa 4\% dihasilkan ketebalan yang agak rendah dibandingkan penambahan sukrosa $6 \%, \quad 8 \%$ dan $10 \%$, ini dikarenakan sumber karbon dalam media fermentasi kurang sehingga selulosa yang dihasilkan juga sedikit, sedangkan perlakuan penambahan sukrosa $12 \%$ dihasilkan ketebalan yang lebih rendah, ini dikarenakan penambahan sukrosa yang berlebih dapat menyebabkan terganggunya pertumbuhan dan perkembangbiakan bakteri, yang mengakibatkan banyak sukrosa yang diubah menjadi asam dan penurunan $\mathrm{pH}$ secara drastis sehingga nata yang dihasilkan juga tidak maksimal.

Konsentrasi gula yang terlalu banyak atau terlalu sedikit diduga dapat menghambat aktivitas Acetobacter xylinum dalam membentuk selulosa (Nisa, dkk. 2001). Hasil penelitian di atas, sesuai dengan pendapat Steinkraus (1983) yang menyatakan bahwa penambahan sukrosa $10 \%$ berat per volume menghasilkan nata de coco yang paling baik berdasarkan ketebalan dan tekstur yang terbentuk. Untuk lebih jelasnya dapat dilihat pada gambar 1 . 


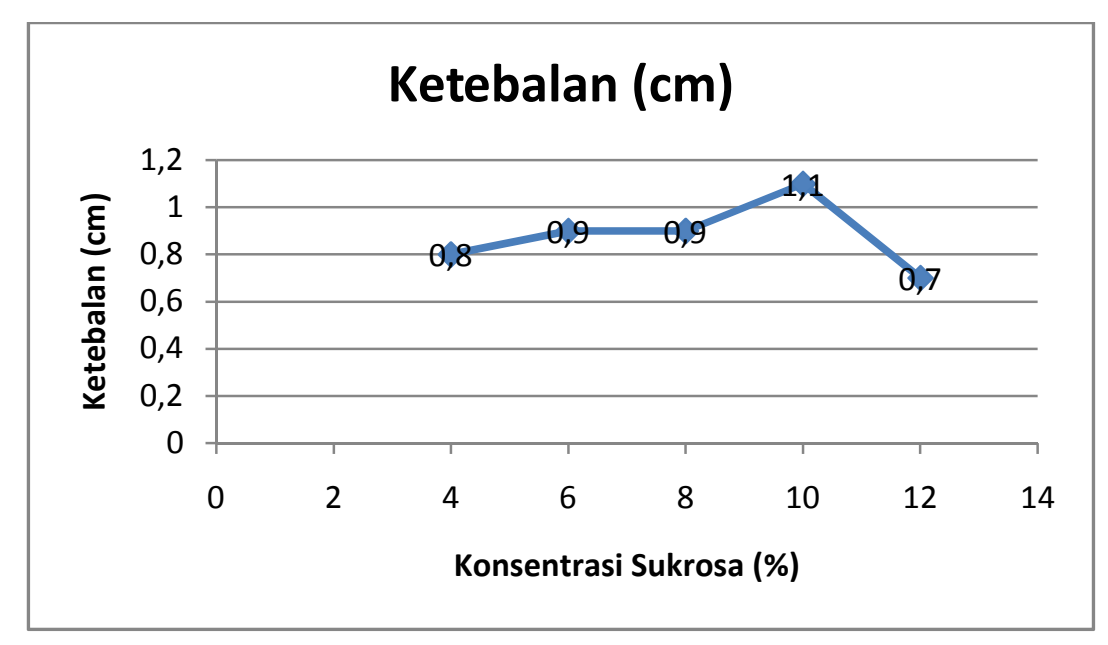

Gambar 1. Grafik Hasil Analisa Rerata Ketebalan Nata Timun Suri

Dari gambar 1. terlihat bahwa ketebalan nata timun suri dengan variasi konsentrasi sukrosa yang berada pada konsentrasi optimum adalah pada penambahan sukrosa $10 \%$.

\section{Tekstur Nata Timun Suri}

Berdasarkan hasil rerata analisa pengukuran tekstur nata timun suri dengan perlakuan variasi konsentrasi sukrosa dapat dilihat pada tabel 2 dan gambar 2.

Tabel 2 menjelaskan bahwa masingmasing perlakuan terdapat perbedaan yang nyata terhadap tekstur nata. Tekstur nata timun suri dengan perlakuan konsentrasi sukrosa $(4 \%, 6 \%, 8 \%, 10 \%$, dan 12\%) terdapat kecenderungan berbeda tidak nyata. Tekstur nata tertinggi terjadi pada perlakuan penambahan sukrosa $12 \%$, yakni $3,4 \mathrm{kgf} / \mathrm{cm}^{2}$, sedangkan tekstur nata terendah terjadi pada perlakuan penambahan sukrosa $8 \%$, yakni $2,5 \mathrm{kgf} / \mathrm{cm}^{2}$.

Pada penambahan sukrosa $6 \%$ dan $12 \%$ didapatkan nilai yang tinggi yaitu 3,17 $\mathrm{kgf} / \mathrm{cm}^{2}$ dan $3,4 \mathrm{kgf} / \mathrm{cm}^{2}$, ini berarti menunjukkan tekstur yang lunak. Hal ini disebabkan karena memiliki ronggarongga yang longgar pada serat-serat yang terbentuk, sehingga memudahkan masuknya air dan menjadikan teksturnya menjadi lunak. Sesuai pendapat (Rahman, 2004) bahwa struktur kimia dan fisik merupakan efek dari susunan air yang terserap dan berpengaruh besar terhadap tekstur. Nilai tekstur dipengaruhi oleh kandungan air pada produk pangan.

Nilai tekstur rendah terdapat pada penambahan sukrosa $4 \%$ dan $10 \%$ dengan nilai sama-sama $2,57 \mathrm{kgf} / \mathrm{cm}^{2}$ serta penambahan sukrosa $8 \%$ dengan nilai 2,5 $\mathrm{kgf} / \mathrm{cm}^{2}$ yang berarti memberikan tekstur yang kenyal. Ini disebabkan karena 
rapatnya selulosa yang terbentuk sehingga air sulit masuk pada rongga-rongga pelikel tersebut dan menjadikan tekstur nata menjadi lebih kenyal. Kenyataan hasil penelitian diatas, sesuai dengan pendapat Fahnum (2003) yang menyatakan bahwa nilai tekstur yang makin tinggi menunjukkan tekstur yang makin lunak dan nilai tekstur yang makin rendah menunjukkan tekstur yang makin kenyal.

Dari gambar 2 terlihat bahwa tekstur nata timun suri dengan variasi konsentrasi sukrosa yang memberikan tekstur yang kenyal adalah pada penambahan sukrosa 4\%, 8\% dan 10\% senada dengan hasil uji sensoris untuk parameter tekstur yang tidak beda nyata.

\section{Tabel 2. Hasil Analisa Tekstur $\left(\mathrm{kgf} / \mathrm{cm}^{2}\right)$ Nata Timun Suri}

\begin{tabular}{|c|c|}
\hline Konsentrasi Sukrosa (\%) & Tekstur $\left(\mathrm{kgf} / \mathrm{cm}^{2}\right)$ \\
\hline 4 & $2.57^{\mathrm{bc}}$ \\
\hline 6 & $3.17^{\mathrm{ab}}$ \\
\hline 8 & $2.5^{\mathrm{c}}$ \\
\hline 10 & $2.57^{\mathrm{c}}$ \\
\hline 12 & $3.4^{\mathrm{a}}$ \\
\hline
\end{tabular}

Keterangan : Angka yang diikuti oleh kode huruf yang berbeda menunjukkan adanya perbedaan yang nyata pada taraf signifikansi $5 \%$.

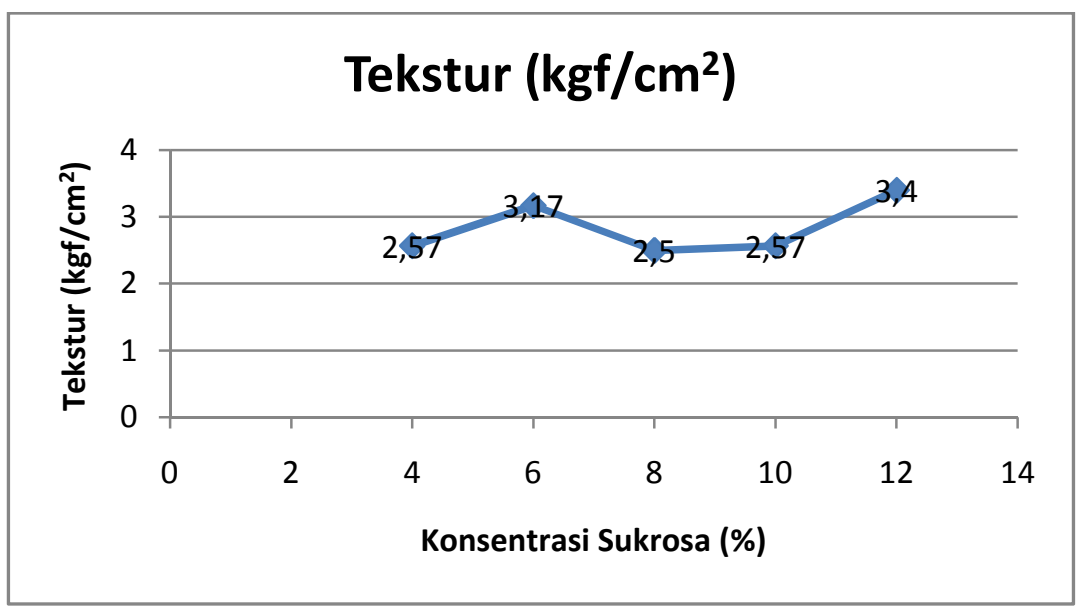

Gambar 2. Grafik Hasil Analisa Rerata Tekstur Nata Timun Suri 


\section{Kadar Serat Nata Timun Suri}

Keunggulan dari produk nata adalah kandungan seratnya yang cukup tinggi terutama selulosa. Peran utama serat dalam makanan adalah pada kemampuannya mengikat air yang dapat melunakkan feses. Berdasarkan hasil rerata analisa kadar serat nata timun suri dengan perlakuan variasi konsentrasi sukrosa dapat dilihat pada tabel 3 dan gambar 3 .

Tabel 3 menjelaskan bahwa masingmasing perlakuan terdapat perbedaan yang nyata terhadap kadar serat nata. Kadar serat nata timun suri dengan perlakuan konsentrasi sukrosa $(4 \%, 10 \%$, dan $12 \%$ ) terdapat beda nyata, sedangkan perlakuan konsentrasi sukrosa $(6 \%$ dan $8 \%)$ tidak beda nyata. Kadar serat yang tinggi yaitu pada perlakuan penambahan sukrosa $10 \%$, yakni $1,11 \%$, sedangkan kadar serat yang rendah yaitu pada perlakuan penambahan sukrosa $8 \%$, yakni $0,97 \%$.

Pada perlakuan penambahan sukrosa $4 \%$ dan $10 \%$ didapatkan tekstur yang kenyal dengan kadar serat yang tinggi, yaitu $1,02 \%$ dan $1,11 \%$, sedangkan pada perlakuan penambahan sukrosa $6 \%$ dan $12 \%$ didapatkan tekstur yang lunak dengan kadar serat yang rendah, yaitu 0,98\% dan 0,99\%. Persentase kadar serat yang tinggi dipengaruhi oleh aktivitas dari Acetobacter xylinum pada proses metabolisme sukrosa menjadi selulosa (Wijayanti, dkk, 2012).

Pada perlakuan penambahan sukrosa $8 \%$ didapatkan tekstur yang kenyal dengan kadar serat yang rendah, yaitu $0,97 \%$. Hal ini diduga karena adanya kontaminasi sehingga mengganggu aktivitas pertumbuhan dan perkembangbiakan bakteri Acetobacter xylinum selama proses fermentasi sehingga serat selulosa yang terbentuk kurang maksimal dan sedikit. Ruangan tempat fermentasi harus selalu dibersihkan dan tidak terkena sinar matahari secara langsung (Sutarminingsih, 2004).

Tabel 3 Hasil Analisa Kadar Serat (\%) Nata Timun Suri

\begin{tabular}{|c|c|}
\hline Konsentrasi Sukrosa (\%) & Kadar Serat (\%) \\
\hline 4 & $1.02^{\mathrm{b}}$ \\
\hline 6 & $0.98^{\mathrm{c}}$ \\
\hline 8 & $0.97^{\mathrm{c}}$ \\
\hline 10 & $1.11^{\mathrm{a}}$ \\
\hline 12 & $0.99^{\mathrm{bc}}$ \\
\hline
\end{tabular}

Keterangan : Angka yang diikuti oleh kode huruf yang berbeda menunjukkan adanya perbedaan yang nyata pada taraf signifikansi $5 \%$. 
Berdasarkan syarat mutu nata dalam kemasan menurut SNI 01 - 4317 - 1996 kandungan serat maksimum 4,5\%. Dalam penelitian ini jumlah kadar serat yang paling tinggi kurang dari 4,5\% yakni $1,11 \%$, ini berarti jumlah kadar serat telah memenuhi syarat mutu nata dalam kemasan. Kadar serat sangat penting dalam penilaian kualitas bahan makanan karena angka ini menentukan nilai gizi bahan makanan tersebut (Sudarmadji, 1984).

Dari gambar 3 menunjukkan bahwa kadar serat nata timun suri dengan variasi konsentrasi sukrosa yang memberikan kadar serat yang tinggi adalah pada penambahan sukrosa $10 \%$.

\section{Uji Organoleptik Warna Nata Timun Suri}

Warna merupakan parameter organoleptik yang penting dalam suatu produk makanan. Warna merupakan parameter pertama yang menentukan tingkat penerimaan konsumen terhadap suatu produk. Warna merupakan salah satu atribut mutu yang sangat penting bagi produk olahan pangan, untuk mendapatkan perhatian cukup besar dari para pengusaha industri pengolahan pangan.

Walaupun warna kurang berhubungan dengan nilai gizi, kenyataan membuktikan bahwa sebelum faktorfaktor lain dipertimbangkan, secara visual faktor warna tampil lebih dahulu dan kadang-kadang sangat menentukan. Hasil rerata analisa uji kesukaan warna nata timun suri dengan perlakuan konsentrasi sukrosa dapat dilihat pada tabel 4 dan gambar 4.

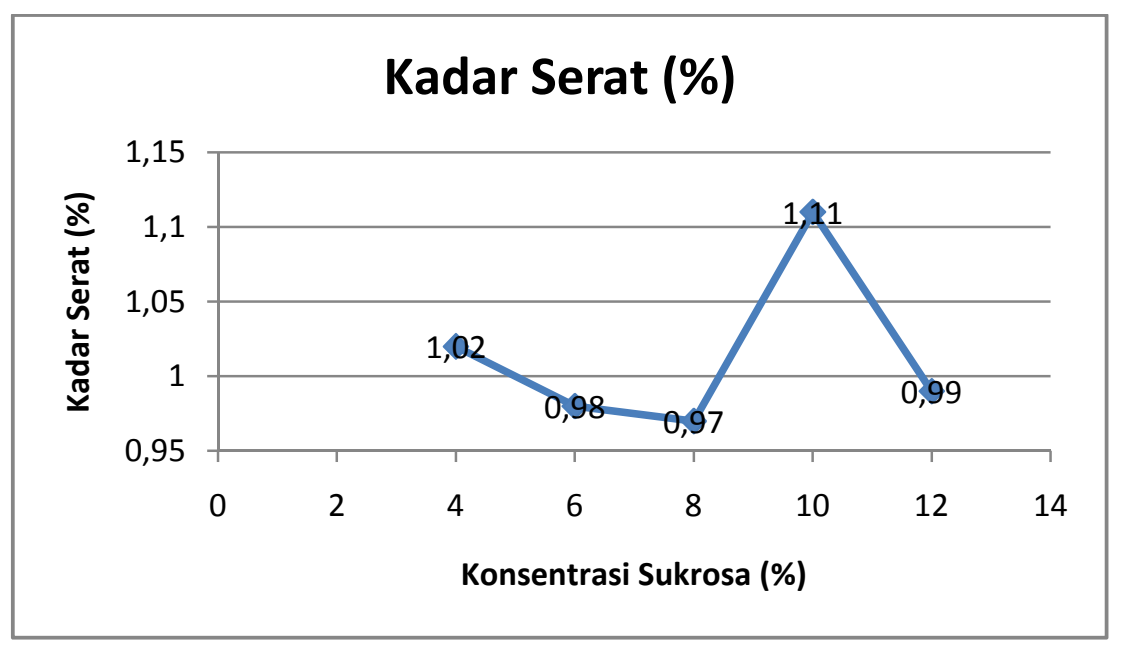

Gambar 3 Grafik Hasil Analisa Rerata Kadar Serat Nata Timun Suri 


\section{Tabel 4. Hasil Nilai Rerata Uji Kesukaan Warna Nata Timun Suri}

\begin{tabular}{|c|c|}
\hline Konsentrasi Sukrosa (\%) & Warna \\
\hline 4 & $2.75^{\mathrm{c}}$ \\
\hline 6 & $3.45^{\mathrm{ab}}$ \\
\hline 8 & $3.15^{\mathrm{bc}}$ \\
\hline 10 & $3.25^{\mathrm{b}}$ \\
\hline 12 & $3.85^{\mathrm{a}}$ \\
\hline
\end{tabular}

Keterangan : Angka yang diikuti oleh kode huruf yang berbeda menunjukkan adanya perbedaan yang nyata pada taraf signifikansi $5 \%$.

Atribut mutu : (1) sangat tidak suka, (2) tidak suka, (3) agak suka, (4) suka, (5) sangat suka.

Berdasarkan tabel 4 menunjukkan bahwa hasil uji organoleptik masing-masing perlakuan terdapat perbedaan yang nyata terhadap warna nata. Warna nata timun suri dengan perlakuan konsentrasi sukrosa $(4 \%, 6 \%, 8 \%, 10 \%$, dan $12 \%)$ cenderung berbeda tidak nyata. Rata-rata nilai kesukaan panelis terhadap warna nata timun suri berkisar antara 2,75 (agak suka) sampai 3,85 (suka).
Perlakuan penambahan konsentrasi sukrosa $12 \%$ dengan nilai tertinggi 3,85 (suka) adalah warna nata yang paling disukai panelis karena berwarna putih layaknya warna nata pada umumnya. Hasil ini menunjukkan bahwa tidak terjadi penyimpangan warna pada nata timun suri, karena sukrosa yang digunakan berfungsi sebagai sumber karbon untuk bakteri bukan sebagai pewarna.

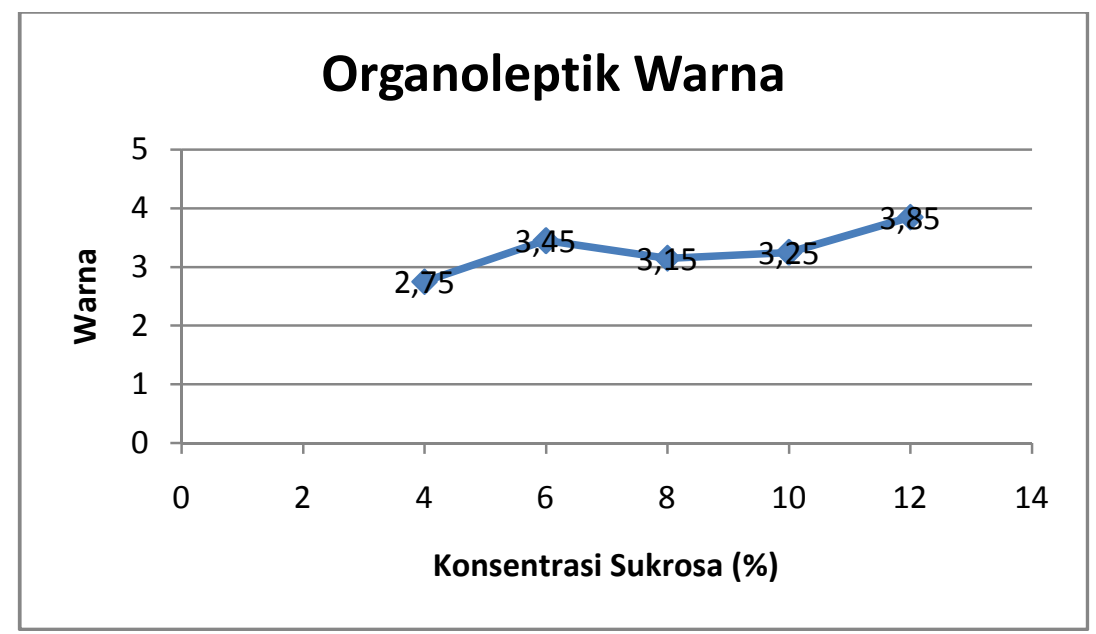

Gambar 4 Grafik Hasil Analisa Rerata Organoleptik Warna Nata Timun Suri 
Dari gambar 4. terlihat bahwa hasil analisa organoleptik warna nata timun suri dengan variasi konsentrasi sukrosa yang paling disukai panelis adalah pada penambahan sukrosa $12 \%$ dengan nilai 3,85 yang berarti suka.

\section{Uji Organoleptik Rasa Nata Timun Suri}

Rasa merupakan tanggapan atas adanya rangsangan kimiawi yang sampai diindera pengecap lidah, khususnya jenis rasa dasar yaitu manis, asin, asam, dan pahit. Pada konsumsi tinggi indera pengecap akan mudah mengenal rasa-rasa dasar tersebut. Beberapa komponen yang berperan dalam penentuan rasa makanan adalah aroma makanan, bumbu masakan dan bahan makanan, keempukan atau kekenyalan makanan, kerenyahan makanan, tingkat kematangan dan temperatur makanan.
Kartika dkk. (1998) makanan merupakan gabungan dari berbagai macam rasa bahan-bahan yang digunakan dalam makanan tersebut. De Mann (2009) mendefinisikan rasa sebagai rangsangan yang ditimbulkan oleh bahan makanan yang dimakan, yang dirasakan oleh indera pengecap atau pembau. Cita rasa merupakan suatu kesan yang diterima melalui saraf indera pengecap, yaitu lidah. Hasil rerata analisa uji kesukaan rasa nata timun suri dengan perlakuan konsentrasi sukrosa dapat dilihat pada tabel 5 dan gambar 5 .

Berdasarkan tabel 5 menunjukkan bahwa hasil uji organoleptik masing-masing perlakuan tidak terdapat perbedaan yang nyata. Rasa nata timun suri dengan perlakuan konsentrasi sukrosa $(4 \%, 6 \%$, $8 \%, 10 \%$, dan 12\%) tidak beda nyata. Rata-rata nilai kesukaan panelis terhadap rasa nata timun suri berkisar antara 3,9 (agak suka) sampai 4,1 (suka).

\section{Tabel 5. Hasil Nilai Rerata Uji Kesukaan Rasa Nata Timun Suri}

\begin{tabular}{|c|c|}
\hline Konsentrasi Sukrosa (\%) & Rasa \\
\hline 4 & $4^{\mathrm{a}}$ \\
\hline 6 & $3.95^{\mathrm{a}}$ \\
\hline 8 & $4^{\mathrm{a}}$ \\
\hline 10 & $4.1^{\mathrm{a}}$ \\
\hline 12 & $3.9^{\mathrm{a}}$ \\
\hline
\end{tabular}

Keterangan : Angka yang diikuti oleh kode huruf yang sama menunjukkan tidak ada perbedaan yang nyata pada taraf signifikansi $5 \%$.

Atribut mutu : (1) sangat tidak suka, (2) tidak suka, (3) agak suka, (4) suka, (5) sangat suka. 
Perlakuan penambahan konsentrasi sukrosa $10 \%$ dengan nilai tertinggi 4,1 (suka) adalah rasa nata yang paling disukai panelis. Hasil analisis ragam menunjukkan bahwa perlakuan konsentrasi sukrosa tidak berbeda nyata. Hal ini disebabkan karena selama proses perendaman dan pemasakan terjadi peristiwa osmosis dan hasil proses tersebut menyebabkan nata memiliki rasa yang hampir sama. Oleh karena itu rasa yang hampir sama tersebut diduga sebagai akibat rasa nata yang sebenarnya hambar, setelah proses perendaman dan pemasakan dengan air gula rasa nata menjadi manis.

Damayanti (2002) menyatakan bahwa rasa suatu bahan pangan dapat berasal dari bahan pangan itu sendiri dan apabila telah mendapatkan perlakuan atau pengolahan maka rasanya akan dipengaruhi oleh bahan yang ditambahkan selama pengolahan. Untuk uji sensoris berdasarkan parameter rasa harus dilakukan pengolahan khusus sebelum dilakukan pengujian agar rasa nata yang hambar dan asam hilang. Rasa nata yang asam akan hilang setelah mendapat perlakuan perendaman berkalikali dengan air dan perebusan. Rasa hambar nata akan hilang apabila setelah mendapat perlakuan perendaman dalam larutan air gula atau dengan perebusan air gula maka rasa nata akan menjadi manis. Tidak ada perbedaan rasa pada nata ini diakibatkan oleh adanya perebusan air gula dengan konsentrasi yang sama pada masing-masing perlakuan.

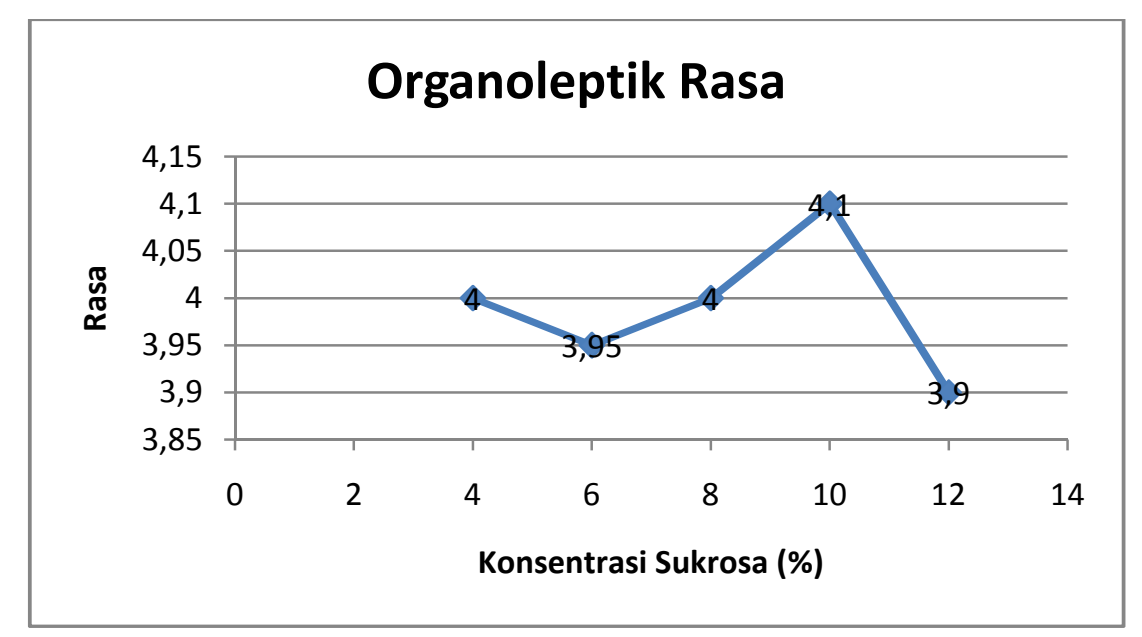

Gambar 5. Grafik Hasil Analisa Rerata Organoleptik Rasa Nata Timun Suri 
Dari gambar 5 terlihat bahwa hasil analisa organoleptik rasa nata timun suri dengan variasi konsentrasi sukrosa yang paling disukai panelis adalah pada penambahan sukrosa $10 \%$ dengan nilai 4,1 yang berarti suka.

\section{Uji Organoleptik Tekstur Nata Timun Suri}

Tekstur (keempukan), penilaian tekstur makanan dapat dilakukan dengan jari, gigi, dan langit-langit (palatum). Dari nilai yang diperoleh diharapkan dapat diketahui kualitas makanan. Faktor tekstur diantaranya adalah rabaan oleh tangan, keempukan, kekenyalan, kemudahan dikunyah serta kerenyahan makanan. Untuk itu cara pemasakan bahan makanan dapat mempengaruhi kualitas tekstur makanan yang dihasilkan.
Tekstur adalah nilai raba pada suatu permukaan, baik itu nyata maupun semu. Suatu permukaan mungkin kasar, halus, keras atau lunak atau licin. Rangsangan sentuhan dapat berasal dari bermacammacam rangsangan yaitu rangsangan mekanik, berasal dari tekanan dan rangsangan fisik, misalnya dalam bentuk rangsangan panas, dingin, basah, kering, keras, lengket, kompak. Tekstur merupakan sensasi tekanan yang dapat diamati dengan mulut atau perabaan dengan jari dan konsistensi merupakan tebal, tipis dan halus. Tekstur dan konsestensi bahan akan mempengaruhi cita rasa bahan. Hasil rerata analisa uji kesukaan tekstur nata timun suri dengan perlakuan konsentrasi sukrosa dapat dilihat pada tabel 6 dan gambar 6 .

\section{Tabel 6. Hasil Nilai Rerata Uji Kesukaan Tekstur Nata Timun Suri}

\begin{tabular}{|c|c|}
\hline Konsentrasi Sukrosa (\%) & Tekstur \\
\hline 4 & $3.7^{\mathrm{a}}$ \\
\hline 6 & $3.65^{\mathrm{a}}$ \\
\hline 8 & $3.65^{\mathrm{a}}$ \\
\hline 10 & $3.75^{\mathrm{a}}$ \\
\hline 12 & $3.95^{\mathrm{a}}$ \\
\hline
\end{tabular}

Keterangan : Angka yang diikuti oleh kode huruf yang sama menunjukkan tidak ada perbedaan yang nyata pada taraf signifikansi 5\%.

Atribut mutu : (1) sangat tidak suka, (2) tidak suka, (3) agak suka, (4) suka, (5) sangat suka. 


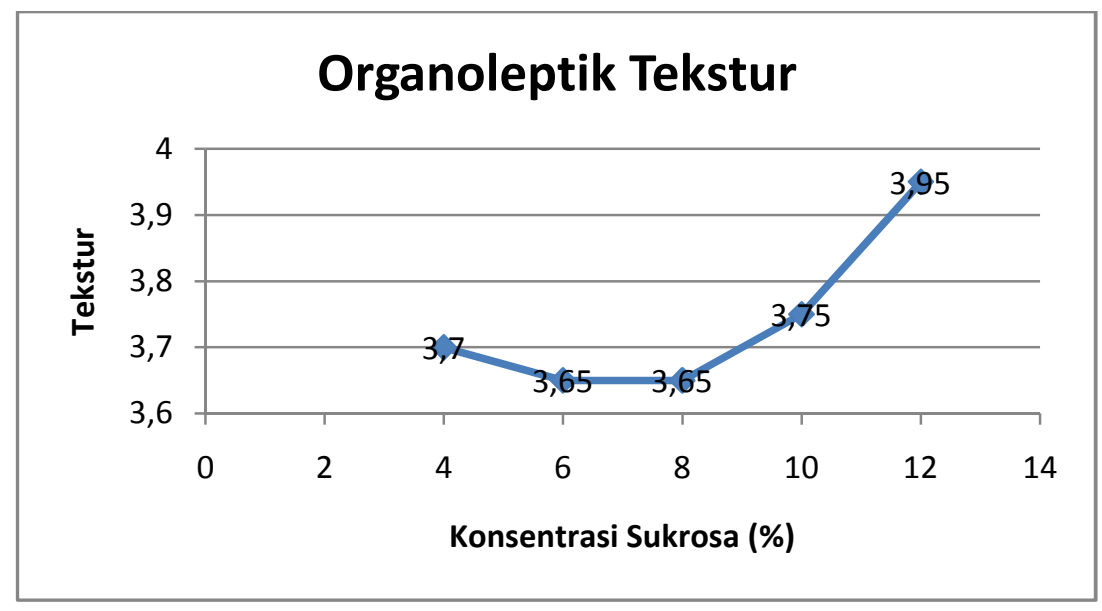

Gambar 6. Grafik Hasil Analisa Rerata Organoleptik

Tekstur Nata Timun Suri

Berdasarkan tabel 6 menunjukkan bahwa hasil uji organoleptik masing-masing perlakuan tidak terdapat perbedaan yang nyata. Tekstur nata timun suri dengan perlakuan konsentrasi sukrosa $(4 \%, 6 \%$, $8 \%, 10 \%$, dan $12 \%)$ tidak beda nyata. Rata-rata nilai kesukaan panelis terhadap tekstur nata timun suri berkisar antara 3,65 (agak suka) sampai 3,95 (suka).

Perlakuan penambahan konsentrasi sukrosa $12 \%$ dengan nilai tertinggi 3,95 (suka) adalah tekstur nata yang paling disukai panelis. Hasil analisis ragam menunjukkan bahwa perlakuan konsentrasi sukrosa tidak berbeda nyata.

Panelis dapat membedakan tekstur nata karena kekenyalan dari nata. Panelis diduga menyukai tekstur nata yang kenyal. Nilai tekstur dipengaruhi oleh kadar air, semakin tinggi nilai kadar air maka nilai tekstur yang diperoleh semakin tinggi (kenyal menurun).

Dari gambar 6 terlihat bahwa hasil analisa organoleptik tekstur nata timun suri dengan variasi konsentrasi sukrosa yang paling disukai panelis adalah pada penambahan sukrosa $12 \%$ dengan nilai 3,95 yang berarti suka.

\section{SIMPULAN}

Dari hasil penelitian yang dilakukan, dapat disimpulkan berdasarkan sifat fisik nata yang dihasilkan bahwa perlakuan terbaik adalah pada perlakuan penambahan konsentrasi sukrosa 10\% dengan ketebalan yaitu $1,1 \mathrm{~cm}$ dan tekstur 2,57 $\mathrm{kgf} / \mathrm{cm}^{2}$, sedangkan sifat kimia berdasarkan kadar serat nata yang dihasilkan perlakuan terbaik adalah pada perlakuan penambahan konsentrasi sukrosa $10 \%$ dengan nilai $1,11 \%$. 
Berdasarkan uji kesukaan terhadap warna nata timun suri yang paling disukai adalah konsentrasi sukrosa $12 \%$ dengan nilai tertinggi yaitu 3,85 karena berwarna putih bersih, dari segi rasa nata timun suri yang paling disukai adalah konsentrasi sukrosa $10 \%$ dengan nilai tertinggi yaitu 4,1 karena rasanya manis, dan dari segi tekstur nata timun suri yang paling disukai adalah konsentrasi sukrosa $12 \%$ dengan nilai tertinggi yaitu 3,95 karena teksturnya kenyal. Hasil penelitian menunjukkan bahwa perlakuan terbaik pada penambahan konsentrasi sukrosa terdapat hubungan bahwa nata yang tebal akan menghasilkan tekstur yang kenyal dan kadar serat yang tinggi. Penambahan konsentrasi sukrosa pada pengolahan nata timun suri yang menghasilkan nata dengan kualitas yang baik adalah pada perlakuan penambahan konsentrasi sukrosa $10 \%$.

\section{DAFTAR PUSTAKA}

Apriyantono, dkk., 1992. Analisis Pangan. Bogor: PAU Pangan dan Gizi.

Damayanti, R.P. 2002. Pembuatan Nata Sari Buah Pepaya (Carica papaya L)Tinjauan dari $\mathrm{pH}$ Awal dan Konsentrasi Sukrosa. Skripsi, Fakultas Teknologi Pertanian. Universitas Brawijaya. Malang.

De, Mann.2009. Principle of food Chemistry. The Avi Pub. Co. In Westport Connecticut (4) : $10-$ 13.
Fahnum, E. 2003. Pengaruh Jenis Konsentrasi Hidrokoloid (Gum Arab dan Karagenan) terhadap Sifat Fisikokimia, Organoloeptik dan Rendemen Tahu. Skripsi. Fakultas Teknologi Pertanian. Universitas Brawijaya. Malang.

Kartika, B.P. Hastuti, W. Supartono. 1998. Pedoman Uji Inderawi Bahan Pangan. UGM Press, Yokyakarta.

Nisa, F.C., R.H. Hani., T. Wastono., B. Baskoro dan Moestijanto. 2001. Produksi Nata Dari Limbah Cair Tahu (Whey) : Kajian Penambahan Sukrosa Dan Ekstrak Kecambah. Jurnal Teknologi Pertanian. 2: $74-78$.

Pratiwi, E. 2006. Karakteristik Nata dari Pulp Kakao Mulia (Theobroma cacao L.) dengan Penambahan Berbagai Konsentrasi Sukrosa. J. Teknologi Pangan dan Hasil Pertanian 5 (2) : 81-85. Semarang.

Purwanto Agus. 2012. Produksi Nata Menggunakan Limbah Beberapa Jenis Kulit Pisang. Widya Warta No. 2 Tahun XXXVI. Madiun.

Rahman. 2004. Pengantar Teknologi Fermentasi. Arcan. Jakarta.

SNI 01- 4317- 1996. Nata dalam Kemasan. Jakarta : Departemen Perindustrian.

Steinkraus, 1983. Handbook of Indigenous Fermented Food. Marcel Deklar Inc., New York.

Sudarmadji. S. 1984. Prosedur Analisa Untuk Bahan Makanan dan Pertanian. Edisi Ketiga. Penerbit Liberty. Yogyakarta.

Sutarminingsih, C.H. 2004. Peluang Usaha Nata de Coco. Kanisius. Yogyakarta.

Warisno. (2004). Mudah dan Praktis Membuat Nata de Coco. Cetakan I. Jakarta: Agromedia Pustaka. Hal. 23-30.

Wijayanti fivien, Sri Kumalaningsih, Mas'ud Effendi. 2012. Pengaruh Penambahan Sukrosa dan Asam 
Asetat Glacial Terhadap Kualitas Nata dari Whey Tahu dan Substrat Air Kelapa. Jurnal Industria Vol 1 No.2 Hal 86-93.

Winarno FG. 2004. Kimia Pangan dan Gizi. PT . Jakarta : Gramedia Pustaka Utama.
Yusmarini, U.Pato, V.S.Johan. 2004. Pengaruh Pemberian Beberapa Jenis Gula dan Sumber Nitrogen terhadap Produksi Nata de Pina. SAGU Vol III No.1 : 20-27. Riau 